\title{
Assessment of the Reproductive Health Status of \\ Clarias Gariepinus (Burchell, 1822) in a River Impacted by Mercury from Clandestine Gold Mining: A Case Study of Bagoue River, Côte d'Ivoire
}

\author{
Augustin KOUAME N'guessan (Corresponding author) \\ Université Felix Houphouët Boigny-UFHB, 22 BP 582 Abidjan 22, Côte d'Ivoire \\ augustkouame.ak@gmail.com
}

Rodrigue Orobiyi Edéya PELEBE

Université de Parakou-UP, 03 BP 61 Parakou, Bénin

Koffi Charles BOUSSOU

Université Jean Lorougnon Guédé-UJLG, BP 150 Daloa, Côte d'Ivoire

\author{
Valentin N'DOUBA
}

Université Felix Houphouët Boigny-UFHB, 22 BP 582 Abidjan 22, Côte d'Ivoire

Received: October 9, 2020 Accepted: November 5, 2020 Published: November 10, 2020

doi:10.5296/ast.v9i1.17766

URL: https://doi.org/10.5296/ast.v9i1.17766

\begin{abstract}
Pollution of aquatic ecosystems often results in adverse environmental disturbances, including individual and/or sub-individual changes in fish. The aim of the present study was to examine possible reproductive health effects in male and female, based on a histological assessment of Clarias gariepinus sampled in Bagoue River impacted by mercury from the artisanal gold mining. Fish were collected between August 2018 and April 2019 during two seasons from four stations differently impacted. A histological assessment was done on three target fish organs (liver, ovary and testis). Water and sediment samples were analysed for
\end{abstract}


total mercury (T-Hg) concentration. Histological alterations were semi-quantitatively assessed, and the results were classified according to the severity of the histological response identified. Microscopic assessment revealed alterations of the gonads and liver tissues. A higher incidence of reaction pattern (Regressive changes, Inflammation and Circulatory disturbance) was found in liver tissues than in gonads tissues (Regressive changes). $\mathrm{T}-\mathrm{Hg}$ levels were higher upstream than downstream in ovaries and testis tissues. Paradoxically, the lesions observed in these organs were more pronounced downstream than those found in fish from upstream during rainy season. According to total index, the organs examined downstream suffered severe damage unlike upstream sites. Also, comparison of degree of alteration between testes and ovaries indicates a greater impact of ovarian structures especially on downstream sites. The effect of anthropogenic impact appears to be visible downstream as the concentration of chemical pollutants and exposure time determine the severity of the damage. Alterations in ovarian follicles, spermatogenic cells and liver tissues may reflect damage to the process of gametogenesis, which may reduce the reproductive capacity of individuals over the long term.

Keywords: Bagoue River, Clarias gariepinus, mercury, histopathology, Côte d'Ivoire

\section{Introduction}

The primary goal of environmental management and conservation of ecosystems is to prevent adverse biological and ecological effects caused by pollution. Indeed, human activities, including mining, waste incineration and the burning of fossil fuels, have led to the increased mobilization of mercury in the environment. Recent data suggest that artisanal gold mining and coal combustion account for about two-thirds of mercury's anthropogenic emissions (Barst, 2015). The mercury emitted is introduced into the atmosphere and deposited in aquatic and terrestrial ecosystems (UNEP, 2002; WHO, 2007). In aquatic environments, mercury undergoes methylation and then easily accumulates and bio amplifies in food webs, resulting in high concentrations in fish (Osman and Wener, 2010). Its presence in the fish's body may alter certain tissues and creates physiological dysfunction (Mc Hugh et al., 2013; Funmilayo et al., 2019).

Various biochemical and biological parameters have been used to assess the consequences of environmental toxicants on fish, but histology is able to enhance and add quality to the research carried out by describing cellular changes (VanDyk et al., 2007) and to quantify the results (Bernet et al., 1999; Marchand et al., 2009). Lower level responses such as the prevalence of histopathological symptoms in fish is indicative of the general quality of the environment and can be related to contamination levels of pollutants such as heavy metals. These pollutants induce pathological changes in fish. The histological assessment of fish tissue has relevance as a bio-assessment tool and serves as a method to determine preserved biochemical and physiological changes, caused by pollutants as they occur in situ (Short and Meyers, 2001).

In West Africa, Côte d'Ivoire is known as one of the main countries where artisanal gold mining is growing so rapidly (Kone, 2017) especially in the North of the country. Mercury is widely used by rural communities engaged in this activity as indicated in the report on the 


\section{Macrothink

mapping of the illicit gold trade in Côte d'Ivoire, Mali and Burkina (Zuzia et al., 2017). Consequently, these artisanal activities of gold extraction are viewed as a major source of pollution of Bagoue River, particularly in the downstream sections, where illegal gold mining is more intense.

The degradation of water quality of Bagoue River by chemical pollutant restricts its uses and can render a whole water body not only useless, but hazardous to both aquatic life and to the people who use it as main water resource. Several recent studies have been conducted on this basin (N'da et al., 2015; Berte et al., 2019; Mason et al., 2019). But none of them addressed the health aspect of the fish. The present research was therefore undertaken to assess the reproductive health status of Clarias gariepinus from Bagoue River impacted by mercury from artisanal and clandestine gold mining.

\section{Method}

\subsection{Site Selection and Characterization}

The Bagoue River basin, tributary of the Niger stream, is situated in the North of Côte d'Ivoire between longitudes $5^{\circ} 40^{\prime}-7^{\circ} 10^{\prime} \mathrm{W}$ and latitudes $9^{\circ} 15^{\prime}-10^{\circ} 50^{\prime} \mathrm{N}$. Four sites were investigated in the River. The first site (Tk) was located in Kanakono, $24 \mathrm{~km}$ east of Tengrela region at downstream. Geographical coordinates are $6^{\circ} 13^{\prime} \mathrm{W}$ and $10^{\circ} 18^{\prime} \mathrm{N}$. It was considered to be the most impacted by gold mining because this activity takes place not only on the main course of the River, but in its immediate environment. Therefore, this section of the River collects the drainage from most of the waste related to gold mining. The Samorossoba site (Ks) is still going up the River towards Kouto, which is still downstream. Kouto is an extension of gold mining activities from Tengrela region. This site is located at the geographic coordinates of $6^{\circ} 21^{\prime} \mathrm{W}$ and $9^{\circ} 52^{\prime} \mathrm{N}$. The two others sites (Bs and $\mathrm{Bg}$ ) were located respectively at Samorosso and Guinguereni villages at upstream in Boundiali region. The geographical coordinates of Bs site are $6^{\circ} 30^{\prime} \mathrm{W}$ and $9^{\circ} 34^{\prime} \mathrm{N}$, while those of the $\mathrm{Bg}$ site are $6^{\circ} 35^{\prime} \mathrm{W}$ and $9^{\circ} 32^{\prime} \mathrm{N}$. They were chosen as reference sites because of their remoteness from the areas of intense artisanal mining on the River (Figure 1). 


\section{Macrothink}

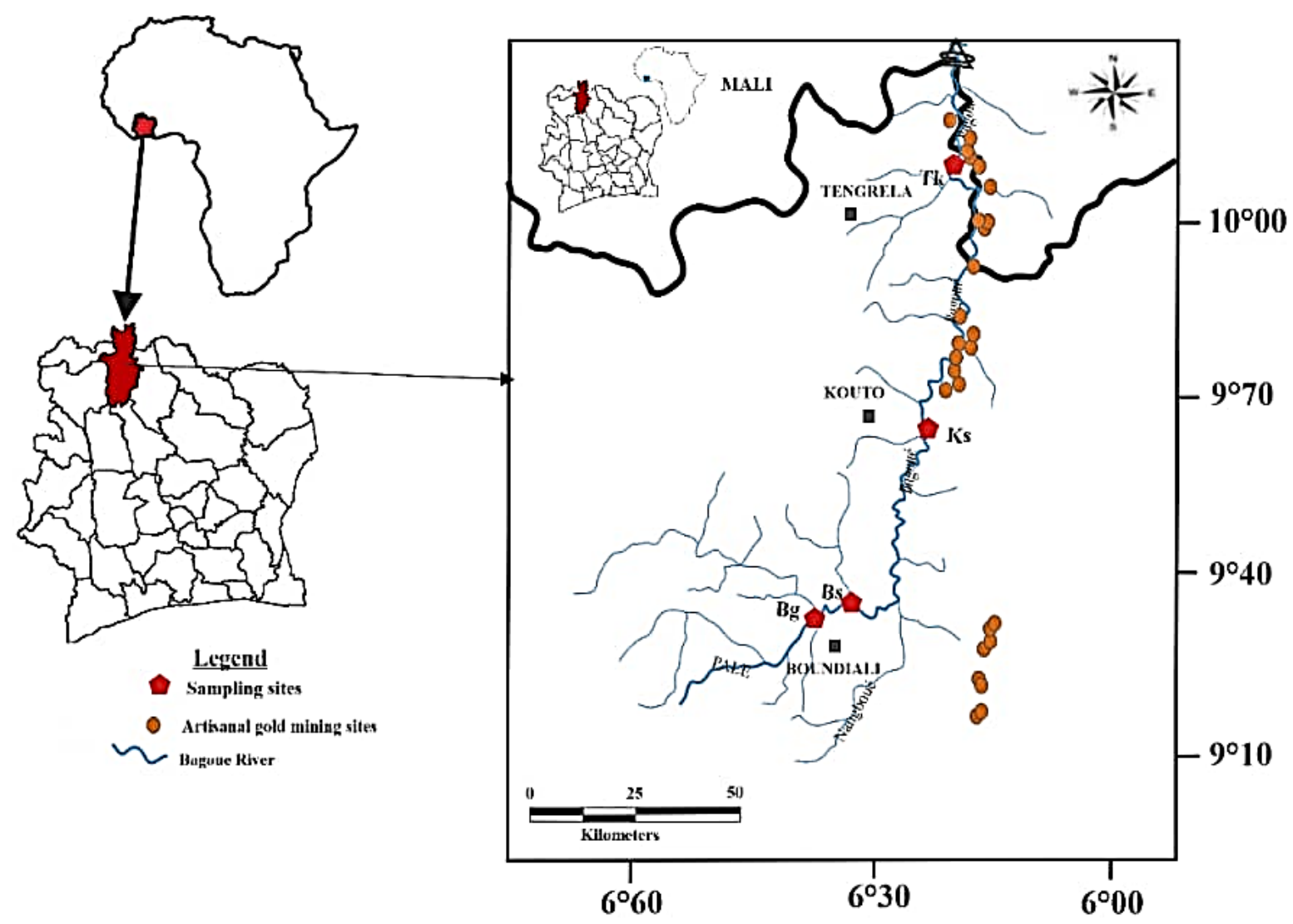

Figure 1. Map of the Bagoue River watershed in Côte d'Ivoire with sampling position sites

\subsection{Data Sampling and Processing}

\subsubsection{Water and Sediment Sampling}

The study was conducted during the rainy season (August and November 2018), period of flooding, and during the dry season (January and April 2019), period of intense use of mercury for gold amalgamation. Water samples were collected using sterile gloves (Ghestem et al., 2008) at a depth of $10 \mathrm{~cm}(\mathrm{CCME}, 2011)$, filtered through a $45 \mu \mathrm{m}$ porous filter and packaged in $1000 \mathrm{ml}$ sterilized vials. Sediment samples were excavated from an area of 25 cm X $25 \mathrm{~cm}$ (Donkor and Adimado, 2016) with hands (Niane et al., 2014 ; Mason et al., 2019), with depth penetration of $8 \mathrm{~cm}$ (CCME, 2011). They were then stabilized by addition of 1 percent concentration hydrochloric acid (AFNOR, 1997). All samples were kept in relabelled polyethylene vials, wrapped in aluminium foil and stored at $4{ }^{\circ} \mathrm{C}$ to the laboratory according to CEAEQ (2015) and AFNOR (1997).

\subsubsection{Fish and Tissues Collection}

African catfish as an important commercial value and has been selected as sentinel species of pollution. It resides and leads its entire life cycle in the River. Clarias gariepinus is an omnivorous specie which bio-accumulates chemicals pollutants. This specie is well distributed in the Bagoue River. African catfish specimens were caught by professional fishermen using gill nets and longlines. Only live fish were taken into account for the study. A total of 42 fish (27 males and 15 females) were examined during the rainy season and 19 (11 
males and 8 females) during the dry season. Each specimen was weighed, standard length measured and sex determined after dissection.

For the $\mathrm{T}-\mathrm{Hg}$ analysis, liver and gonads were collected and individually wrapped in aluminium foil. They were then packaged in small plastic bags by type of organs. Labels have been worn on these bags. All samples were stored in an ice chest at $4{ }^{\circ} \mathrm{C}$ and transported to the laboratory.

For the histopathological analysis, 24 (12 males and 12 females) specimens were tested during the rainy season and 19 (11 males and 8 females) during the dry season. A $5 \mathrm{~mm}$ piece of liver tissue was sampled centrally, around the main portal vein. A $5 \mathrm{~mm}$ midsection of the gonads were sampled. These samples were stored in pillboxes containing $10 \%$ of a formaldehyde solution and transported to the laboratory.

\subsubsection{Mercury Analysis}

T-Hg was tested in the samples (water, sediment, liver and gonads) in a unit of the National Agricultural Development Support of Abidjan (Côte d'Ivoire). T-Hg was analysed by atomic absorption spectrophotometry equipped with a cold vapour system (VGA 77). All analyses were done in triplicate.

\subsubsection{Gonad and Liver Histology}

\section{Tissue processing and analysis}

The histological analysis was carried out in the Pathological Anatomy Laboratory of the Medical Sciences Training and Research Unit (Felix Houphouët Boigny University, Abidjan, Côte d'Ivoire). The mid-sections of the gonads (males and females) and liver were fixed in a $10 \%$ formaldehyde solution since the sampling sites. The tissues were then dehydrated through a graded series of methanol, cleared with toluene, and embedded in paraffin. The tissues were cut into a series of $5 \mu \mathrm{m}$ sections (Agbohessi et al., 2015) using a LEICA RM 2125 RTS-branded Microtom and a paraffin section was mounted on every $50 \mu \mathrm{m}$. For the histological analysis, slides were stained with hematoxylin-eosin (HE). Hematoxylin is a basic dye that colours the cell nucleus blue/purple. On the other hand, eosin is an acid dye that colours the cytoplasm pink. The cuts were mounted between blade and slat with synthetic resin (Eukitt). The blades were examined using MOTIC B 113-branded photonic microscope at a range of magnifications (4-10X).

\section{Histopathological assessment}

A semi-quantitative assessment protocol was used to quantify histopathological alterations observed in the sections of each organ as in Pèlèbè et al. (2017). A qualitative histopathological assessment was done jointly using a photonic microscope. Tissue sections were scanned on 4 and 10X magnification. The results were semi-quantitatively assessed using part of a scoring system (van Dyk et al. 2009a; van Dyk et al. 2009b), modified from the protocol by Bernet et al. (1999) as in Pèlèbè et al. (2017). Thus, three organs indices were calculated: liver index $\left(\mathrm{I}_{\mathrm{L}}\right)$, testis index $\left(\mathrm{I}_{\mathrm{T}}\right)$ and ovary index $\left(\mathrm{I}_{\mathrm{O}}\right)$. These organs indices were calculated for each specimen. Mean of each organ index was calculated according to 


\section{Macrothink}

Aquatic Science and Technology

ISSN 2168-9148 2021, Vol. 9, No. 1

sampling sites and climatic seasons. The sum of the three organ indices yielded a total fish index value. According to Bernet et al. (1999), the formula used to calculate these indices is:

Iorg $=\sum_{\mathrm{rp}} \sum_{\text {alt }}$ (calt $\times$ walt $)$

Where $\mathrm{rp}=$ reaction pattern, alt $=$ alteration, $\alpha=$ score value and $\omega=$ importance factor. These indices were used to compare the occurrence severity of gonad and liver histological alterations between the fish from each site and each season according to a classification system (Van Dyk et al., 2009a; Van Dyk et al., 2009b):

Class 1 (index < 10): Normal tissue structure with slight histological alterations.

Class 2 (index 10-25): Normal tissue structure with moderate histological alterations.

Class 3 (index 26-35): Pronounced alteration of organ tissues.

Class 4 (index > 35): Severe alteration of organ tissues.

In addition to the indices calculated for the extent (score value) and pathological importance (importance factor) of the alterations, the prevalence of histopathological features was assessed. The prevalence of every alteration was calculated as a percentage occurrence of an alteration within all of the fish at each site and climatic season:

Prevalence of histological alteration $=$ (number of fish with the alteration/total number of fish examinated) $\times 100$.

To compare the overall health status based on the histological alterations, a total index ( $\left.\mathrm{I}_{\mathrm{T}}\right)$ was calculated according to Bernet et al. (1999), by summing up all of the organs indices of individual fish. It was calculated as follows:

$$
\mathrm{IT}_{\mathrm{T}}=\mathrm{Ig}_{\mathrm{g}}+\mathrm{I}_{1}
$$

Where $\mathrm{I}_{\mathrm{T}}=$ total index, $\mathrm{I}_{\mathrm{g}}=\operatorname{gonad}\left(\right.$ testis and ovary) index and $\mathrm{I}_{1}=$ liver index.

\subsection{Factor Condition}

The total length and weight of each sampled fish were recorded to calculate the Fulton conditioning factor according to the following formula (Agbohessi et al., 2015):

$\mathrm{K}=\frac{\mathrm{W}}{\mathrm{LS}^{\mathrm{a}}} \mathrm{x} 100$

Where $\mathrm{K}=$ factor condition, $\mathrm{W}=$ body weight $(\mathrm{g})$ and $\mathrm{LS}=$ standard length $(\mathrm{cm})$. The condition index was determined to assess the influence of mercury in fish's body on its physiological condition.

\subsection{Statistical Analysis}

The results were expressed as mean \pm standard deviation. Mercury level, condition factor and 
semi-quantitative histopathological results were tested among climatic season using the non-parametric Mann-Whitney U-test. Statistical differences were considered to be significant at $p<0.05$. The same data were statistically compared among stations using a Kruskall-Wallis test. Significance was tested at an alpha value of 5\%. All statistical analyses were performed using XLSTAT 2016 and PAST3 softwares.

\section{Results}

\subsection{Mercury Loads}

\subsubsection{Water and Sediment}

Data collected at each site for T-Hg analysis in water and sediment (Figure 2) showed no statistical variation (Kruskall-Wallis, $P>0.05$ ) among sites for both aquatic matrix. On the other hand, by comparing the levels of $\mathrm{T}-\mathrm{Hg}$ in water and sediment, a very significant difference (Mann-Whitney, $p<0.05$ ) between the two components of the River was noted. The average concentrations of metal in sediment were higher than those of water at each sampling site. Average concentrations vary from $0.089 \mathrm{mg} \cdot \mathrm{kg}^{-1}$ (Tk site) to $0.044 \mathrm{mg} \cdot \mathrm{kg}^{-1}$ (Bs site) in sediment while values are between $0.70 .10^{-3} \mathrm{mg} . \mathrm{L}^{-1}$ (Tk site) and $0.64 .10^{-3} \mathrm{mg} . \mathrm{L}^{-1}$ (Bg site) in water.
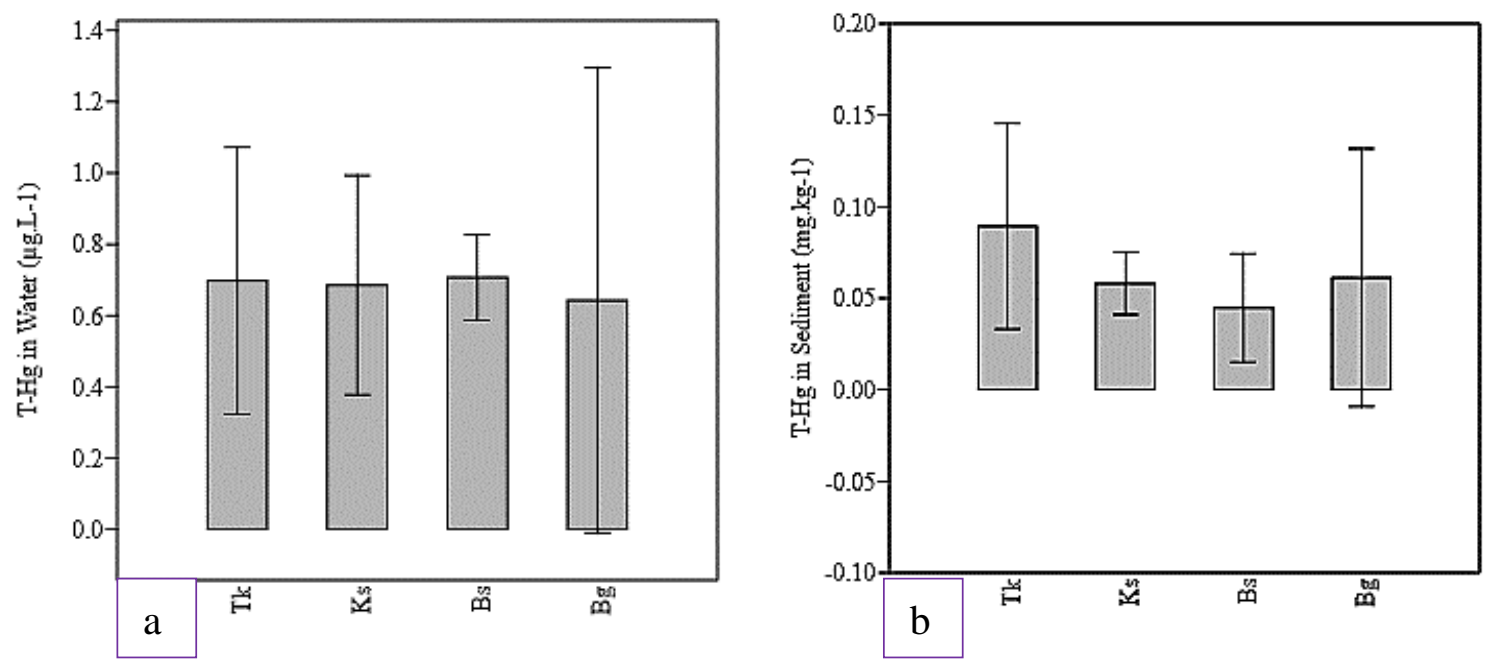

Figure 2. T-Hg levels in water (a) and sediment (b) at sampling sites from Bagoue River

The seasonal variation of T-Hg levels in water and sediment samples are reported in Figure 3. Data showed significant seasonal fluctuations (Mann-Whitney, $p<0.05$ ) in sediment levels of $\mathrm{T}-\mathrm{Hg}$. Average concentration in sediment was higher during dry season $\left(0.089 \mathrm{mg} \cdot \mathrm{kg}^{-1}\right)$ than rainy season $\left(0.040 \mathrm{mg} \cdot \mathrm{kg}^{-1}\right)$. But in water, no significant seasonal difference (Mann-Whitney, $p>0.05)$ was observed in $\mathrm{T}-\mathrm{Hg}$ content. 

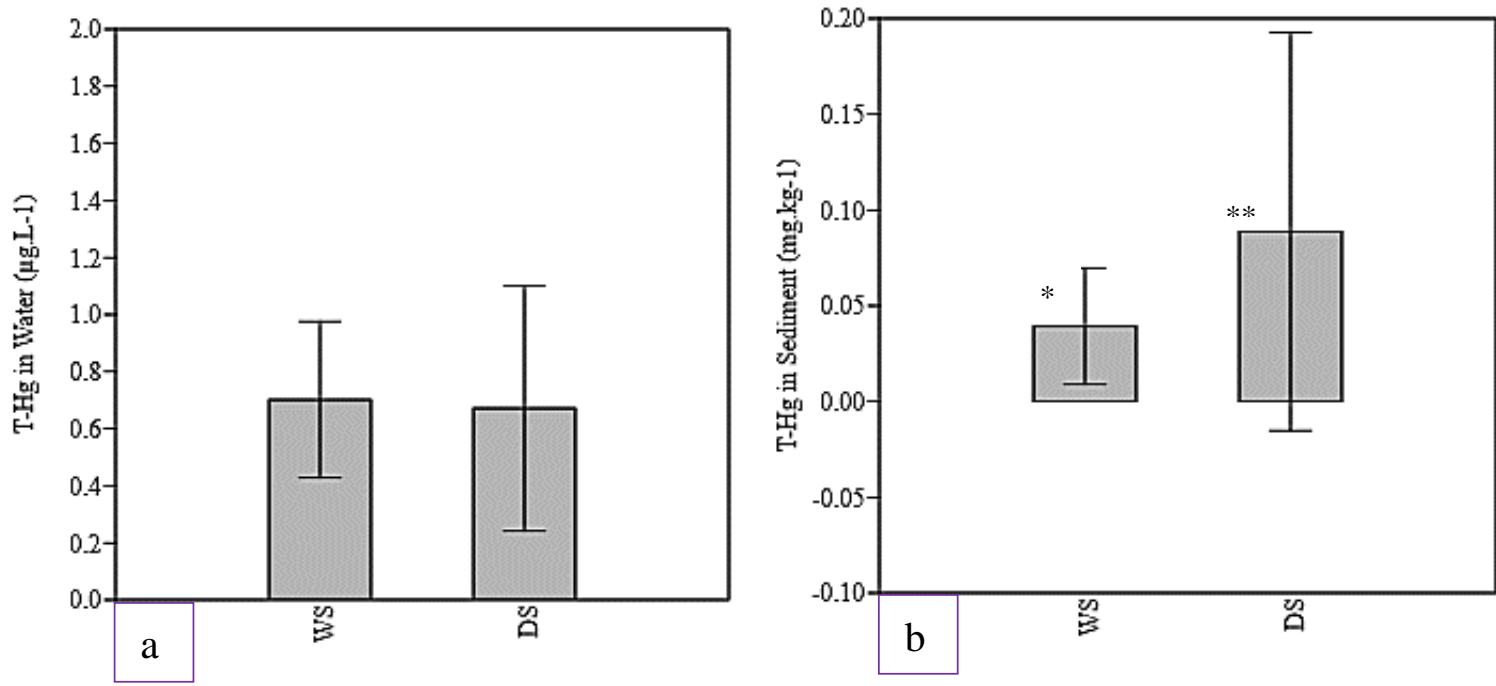

Figure 3. Seasonal variation of T-Hg levels in water (a) and sediment (b) from Bagoue River. WS = wet season; DS = dry season; * indicate a significant difference $(\mathrm{p}<0.05)$

\subsubsection{Fish Tissues}

Spatial variations of T-Hg levels recorded in the Bagoue River were showed in Figure 4. The distribution of pollutant in organs of Clarias gariepinus at the sites indicated a significant variation (Kruskall-Wallis, $P<0.05$ ) for the testis and ovary. Average concentrations of the metal were higher at upstream sites (Bs and $\mathrm{Bg}$ ) than downstream sites ( $\mathrm{Tk}$ and $\mathrm{Ks}$ ) for both organs. $\mathrm{Bg}$ site recorded value of $0.14 \pm 0.11 \mathrm{mg} \cdot \mathrm{kg}^{-1}$ wet weight and $0.28 \pm 0.43 \mathrm{mg} \cdot \mathrm{kg}^{-1}$ respectively in testis and ovary against the values of $0.03 \pm 0.01 \mathrm{mg} \cdot \mathrm{kg}^{-1}$ (Tk site) and $0.025 \pm 0.01 \mathrm{mg} \cdot \mathrm{kg}^{-1}$ (Bs site).
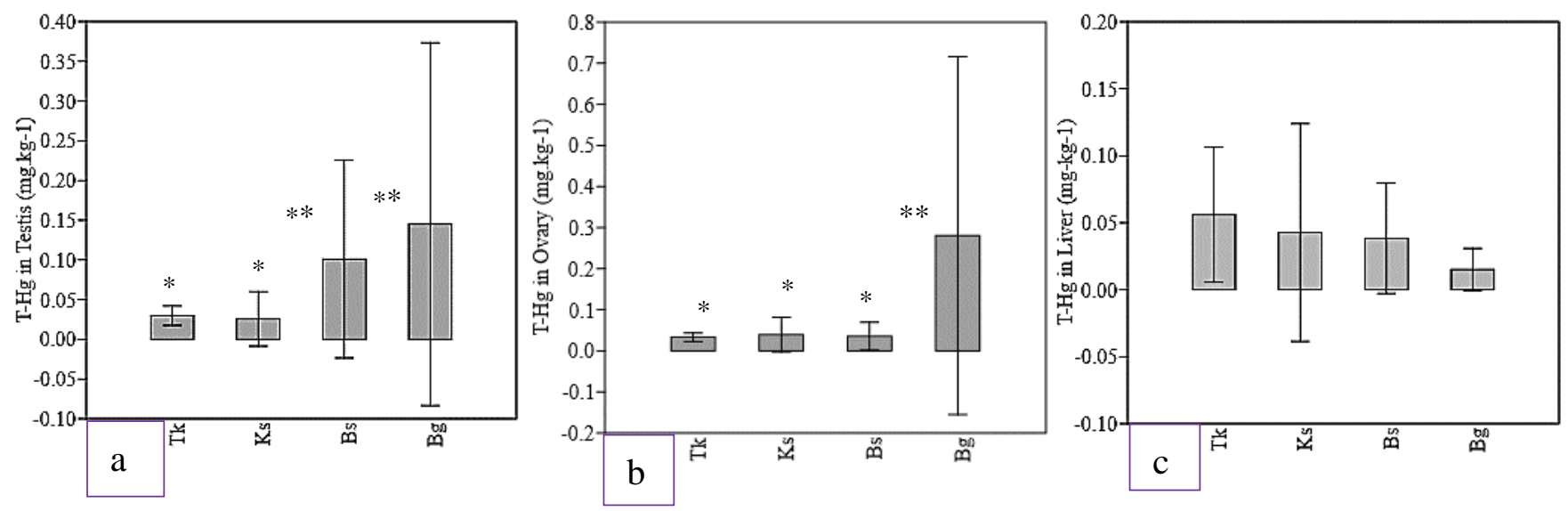

Figure 4. Spatial variation of T-Hg levels in Testis (a), Ovary (b) and Liver (c) of Clarias gariepinus from Bagoue River. * indicate a significant difference between sites $(\mathrm{p}<0.05)$

In terms of climatic seasons, only the ovary showed a significant difference (Mann-Whitney, $p<0.05)$ (Figure 5). Mercury content was higher during dry season $\left(0.163 \pm 0.0304 \mathrm{mg} . \mathrm{kg}^{-1}\right)$ than rainy season $\left(0.031 \pm 0.021 \mathrm{mg} \cdot \mathrm{kg}^{-1}\right)$. 

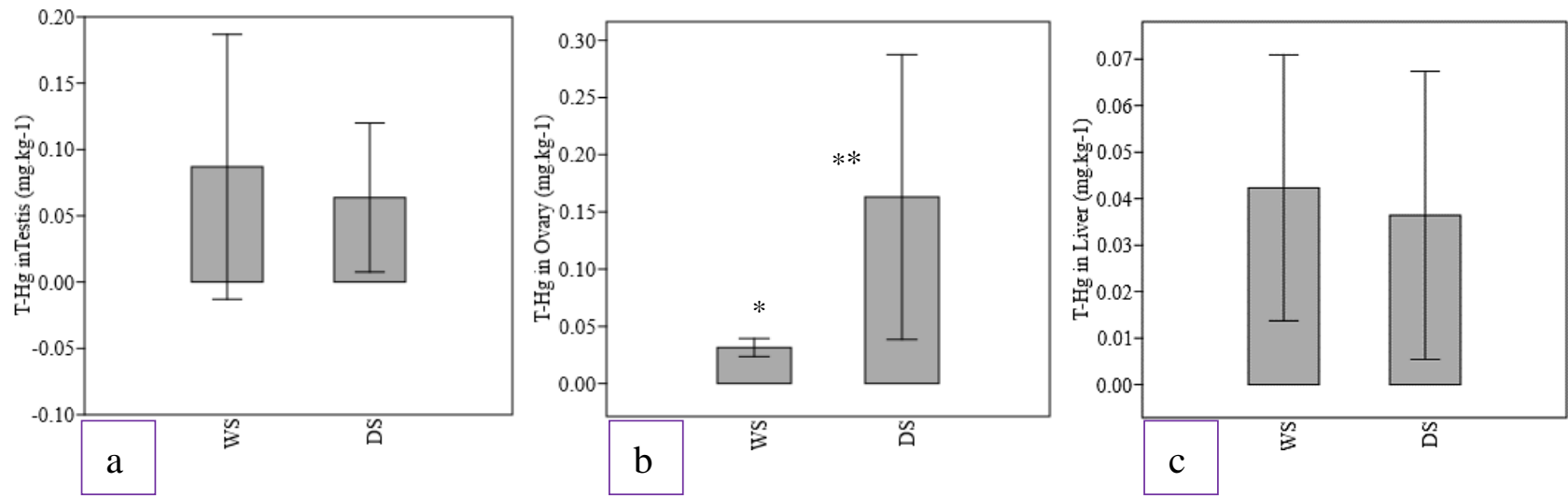

Figure 5. Seasonal variation of T-Hg level in Testis (a), Ovary (b) and Liver (c) of Clarias gariepinus. $\mathrm{WS}=$ wet season; $\mathrm{DS}=$ dry season; $*$ indicate a significant difference $(\mathrm{p}<0.05)$

\subsection{Gonad and Liver Histopathology}

\subsubsection{Histopathology of Testis}

\section{Description and prevalence of histological alterations}

A total of five regressive alterations were identified in testis tissues. These are fibrosis, detachment of lobe basal membrane, decrease in the number of germ cells, disorganization of lobular structures and vacuolation of testicular parenchyma. When lobular structures become disorganized, the seminiferous tubes are devoid of germs cells (Figure 6a). The detachment of the basal membrane is related to a detachment of germ cell cohorts from the underlying epithelium and their dispersion in the light of the seminiferous tube (Figure 6b). The decrease in the number of germ cells observed follows an early degeneration of these cells (Figure 6c). In the case of fibrosis, the interstitial scarring tissues persist (Figure 6d). 


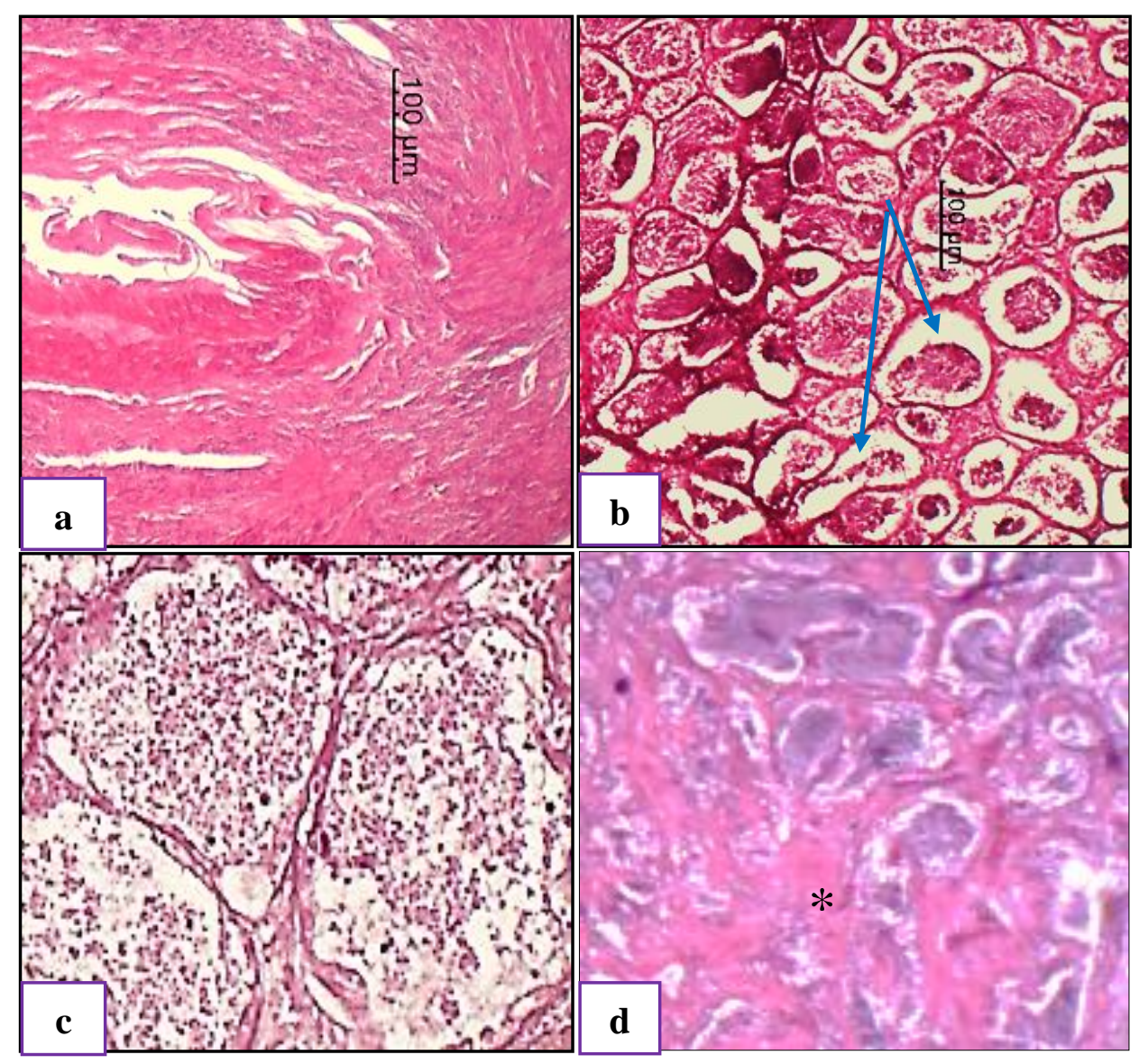

Figure 6. Light micrographs of testis section of Clarias gariepinus collected in the Bagoue

River from August 2018 to April 2019: a) Disorganization of lobular structures; b)

Detachment of lobe basal membrane (blue arrow); c) Decrease in the number of germ cells; d) Interstitial fibrosis (black star) (a, b, d: X4; c: X10)

Testicular abnormalities were identified in all the selected target organs of the studied specie. $60 \%$ of alterations were observed at downstream sites compared to $20 \%$ at upstream sites during the rainy season. These percentages did not vary significantly during the dry season. However, variances in the nature of the alterations were reported from a season to another at the sites. Of the five regressive alterations identified, the detachment of lobe basal membrane was the alteration with the highest prevalence $(100 \%)$ rate during the rainy season in fish sampled at Tk site, whereas the fish sampled at the others sites displayed the lowest percentage. On the other hand, during dry season, interstitial fibrosis was frequently observed $(100 \%)$ in samples from the same site $(\mathrm{Tk})$ as in those of others sites.

\section{Semi-quantitative analysis}

The results of the semi-quantitative testis analysis were presented in Table 1. A significant difference in testis index (Kruskall-Wallis, $p<0.05$ ) was observed during rainy season among the sites. The testis alterations observed in the fish sampled at downstream sites were much more pronounced than those found in fish from upstream sites. During the rainy season, the testis alterations reached class $2(10 \leq \mathrm{It} \leq 25)$ in Clarias gariepinus sampled at the sites 


\section{Macrothink}

Aquatic Science and Technology

ISSN 2168-9148

2021, Vol. 9, No. 1

impacted by artisanal gold mining, compared to upstream sites where they reached class 1 (It $<10)$. No significant differences of testicular index were observed between wet and dry seasons (Mann-Whitney, $p>0.05$ ).

Table 1. Testis index (It) in Clarias gariepinus at sampling sites and seasons

\begin{tabular}{ccc}
\hline Climatic seasons & Sites & Testis index (It) \\
\hline & Tk & $16 \pm 5.65^{\mathrm{a}}$ \\
Wet season & $\mathrm{Ks}$ & $16 \pm 2.82^{\mathrm{a}}$ \\
& $\mathrm{Bs}$ & $14.5 \pm 0.7^{\mathrm{a}}$ \\
& & \\
& $\mathrm{Bg}$ & $5.5 \pm 2.12^{\mathrm{b}}$ \\
& Average & $\mathbf{1 3} \pm \mathbf{5 . 0 4}$ \\
\hline \multirow{4}{*}{ Dry season } & $\mathrm{Tk}$ & $16.5 \pm 0.7$ \\
& $\mathrm{Ks}$ & $20 \pm 11.31$ \\
& $\mathrm{Bs}$ & $23.5 \pm 0.7$ \\
& $\mathrm{Bg}$ & $13.5 \pm 2.12$ \\
\cline { 2 - 3 } & Average & $\mathbf{1 8 . 3 7} \pm \mathbf{4 . 3 2}$ \\
\hline
\end{tabular}

$a$ and $b$ indicate a significant difference between sites $(\mathrm{p}<0.05)$ during Wet season.

\subsubsection{Histopathology of Ovary}

\section{Description and Prevalence of histological alterations}

Five types of alterations, all classified as regressive changes were identified in African catfish females. These are preovulatory atretic follicles, necrosis, fibrosis, large interfollicular spaces and melano-macrophage centers (MMC). Preovulatory follicle necrosis is observed by disintegration (mortification) of vitellogenic protein inclusions in the perinuclear zone (Figure 7a). In the case of follicular atresia, it is characterized by an early degeneration of the follicles (Figure 7a). Ovarian connective tissue fibrosis has also been observed (Figure 7b). The large interfollicular spaces induce the reduction of egg density of ovarian tissue (Figure 7c). Melanomacrophage centers are characterized by clusters of known phagocytic cells through large amounts of generally dark pigments seen in fish ((Figure 7d). 


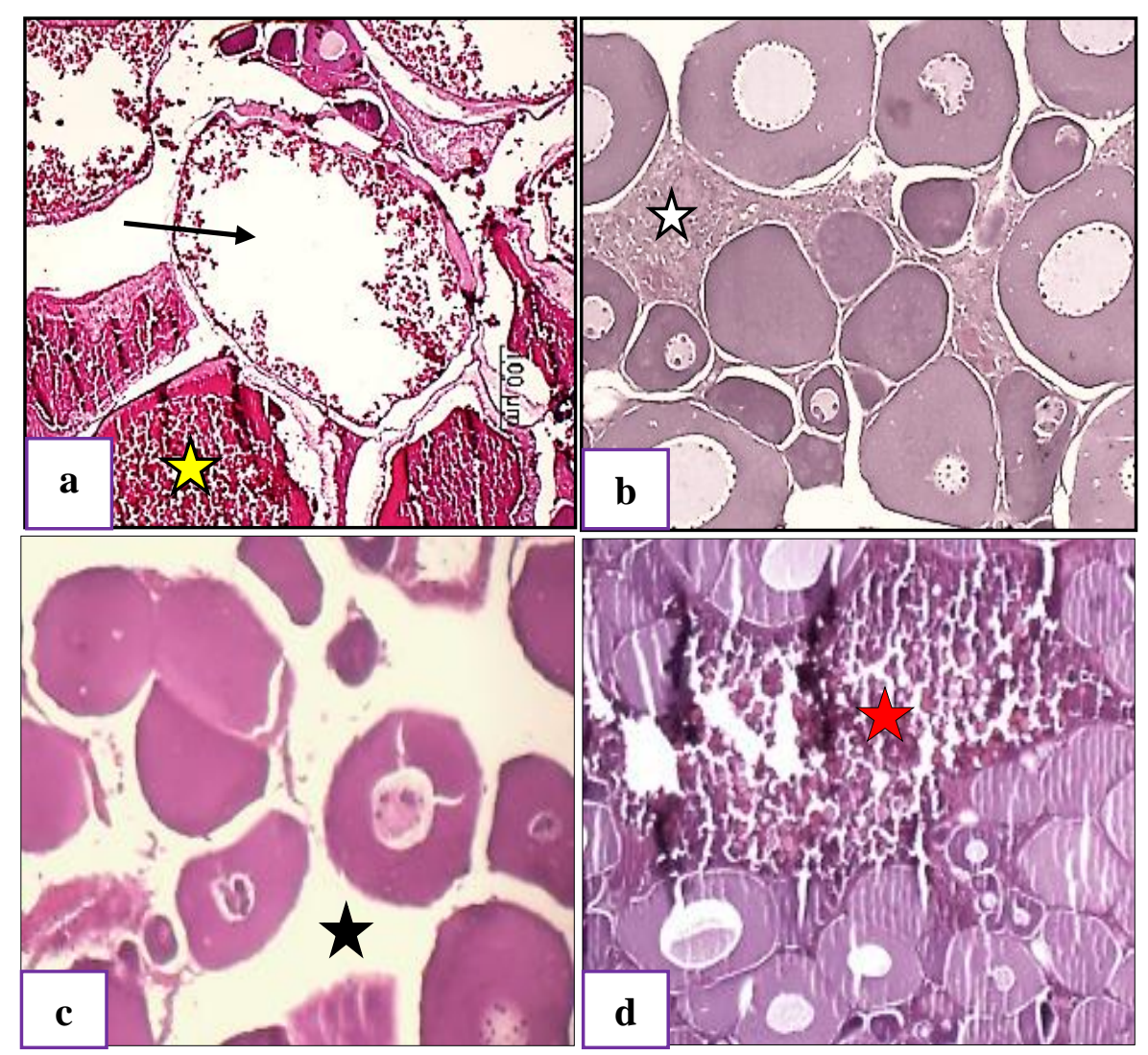

Figure 7. Light micrographs of ovary sections of Clarias gariepinus from Bagoue River showing: a) Peri-vitellogenic necrosis (black arrow) and preovulatory atretic follicles (yellow star); b) Fibrosis (white star); c) Large interfollicular spaces (black star); d)

Melanomacrophage centers (red star); X10

Four alterations ( $80 \%$ of prevalence) were identified downstream while in the upstream, all alterations were observed for both seasons. The most prevalent alterations in fish sampled at downstream have been the presence of MMC (40\%) and interfollicular spaces $(66.66 \%)$ which were observed during the wet season. At the upstream sites, for the same season, necrosis $(100 \%)$, fibrosis $(55.66 \%)$ and atretic follicles $(100 \%)$ were the most frequently alterations observed. During the dry season, all ovarian samples displayed MMC and interfollicular spaces at downstream sites ( $\mathrm{Tk}, \mathrm{Ks}$ ) subject to the influence of gold mining, while upstream, $50 \%$ of the ovary samples showed alterations such as fibrosis, atretic follicles and interfollicular spaces.

\section{Semi-quantitative analysis}

A significant difference in ovary index (Kruskall-Wallis, $p<0.05$ ) was observed between sites during the rainy season (Table 2$)$. The ovary alterations reached class $3(26 \leq$ Io $\leq 35)$ in fish from Tk site, and class 2 from $\mathrm{Ks}$ and $\mathrm{Bs}$ sites, compared to $\mathrm{Bg}$ site where they were classified as class 1 during the rainy season. However, during the dry season, these pathological lesions did not vary significantly (Kruskall-Wallis, $p>0.05$ ) according to the sites. Similarly, no significant statistical variation (Mann-Whitney, $p>0.05$ ) was reported between seasons at each site. A comparison between the testes and ovaries alterations at each 
site indicated that the ovarian structures were more impacted than the testis structures notably on the Tk site (Mann-Whitney, $p<0.05$ ).

Table 2. Ovary index (Io) in Clarias gariepinus at sampling sites and seasons

\begin{tabular}{ccc}
\hline Climatic seasons & Sites & Ovary index (Io) \\
\hline & Tk & $32.5 \pm 2.12^{\mathrm{a}}$ \\
& Ks & $12.5 \pm 0.7^{\mathrm{b}}$ \\
Wet season & & \\
& Bs & $16 \pm 11.31^{\mathrm{b}}$ \\
& & \\
& Bg & $9.5 \pm 0.7^{\mathrm{b}}$ \\
& Average & $\mathbf{1 7 . 6 2} \pm \mathbf{1 0 . 6 2}$ \\
\hline & Tk & $15.5 \pm 2.12$ \\
Kry season & Bs & $11 \pm 4.24$ \\
& Bg & $11.5 \pm 0.7$ \\
& Average & $\mathbf{1 4 . 8 7} \pm \mathbf{4 . 8 5}$ \\
\hline
\end{tabular}

$a$ and $b$ indicate a significant difference between sites $(\mathrm{p}<0.05)$ during Wet season.

\subsubsection{Histopathology of Liver}

\section{Description and Prevalence of histological alterations}

A variety of histopathological abnormalities were displayed in liver tissue. These included primarily regressive changes (melanomacrophage centers, nuclear pleomorphisms, cell necrosis, intracellular deposits and vacuolization), but also inflammation (perivascular inflammatory infiltration) and circulatory disturbance (blood vessel congestion) (Figure 8). The alteration associated with infiltration (Figure 8b) is characterized by a deposition of substances from perivascular fibrillary. In the case of nuclear pleomorphism (Figure 8c), liver cells are coated in different shapes with irregular nuclei in size and shape. Liver cell necrosis reflect early degeneration processes (Figure 8d). Intracellular deposits (Figure 8e) are deposits due to altered debris between other cells. Blood vessel congestion (Figure 8f) is an abnormality characterized by concentric fibrosis of cellular debris. 


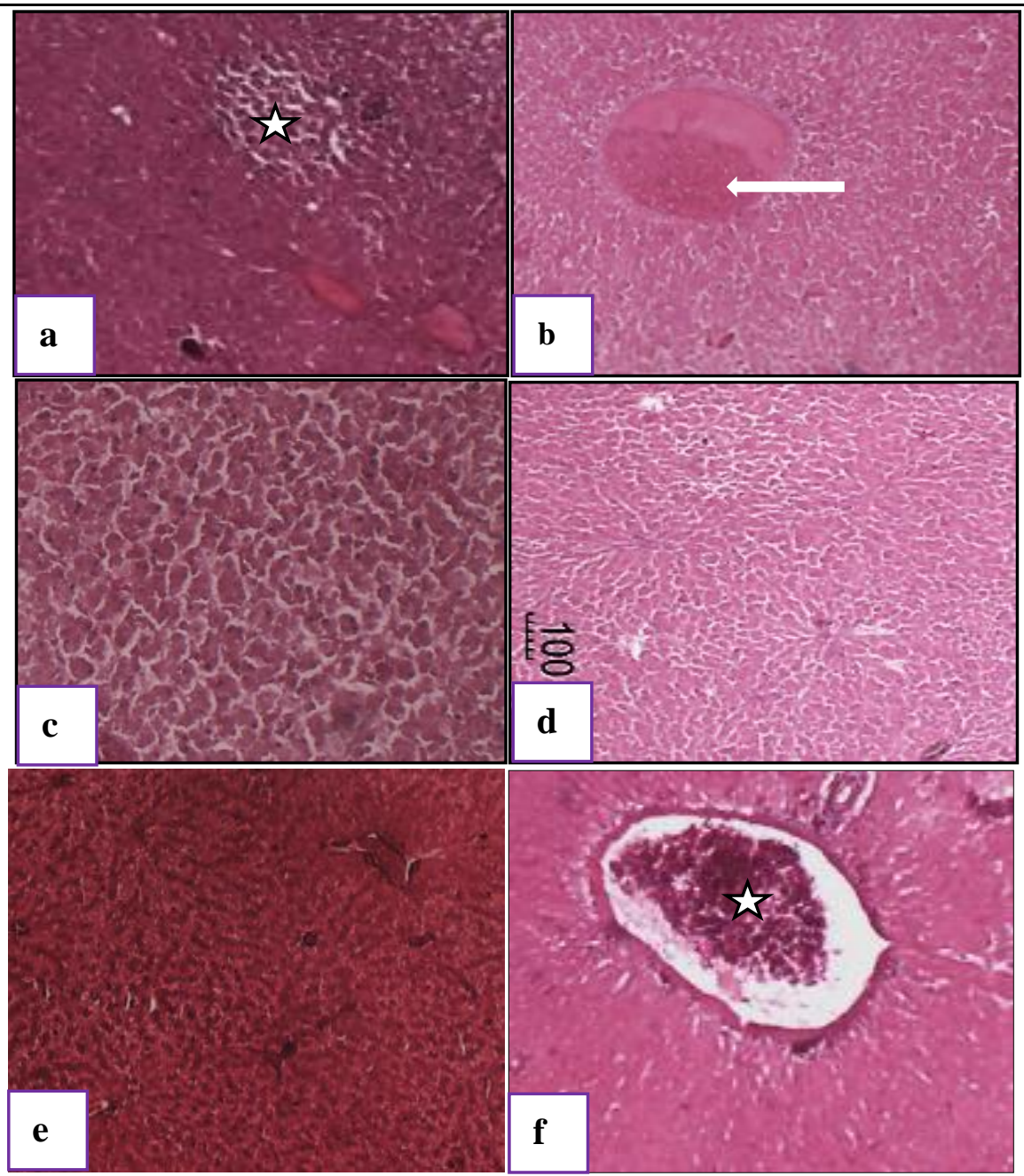

Figure 8. Light micrographs of liver sections of African catfish from Bagoue River showing: a) Melanomacrophagic centers (white star); b) Perivascular inflammatory infiltration (white arrow); c) Nuclear pleomorphisms; d) Cell necrosis; e) Intracellular deposits; f) Blood vessel congestion (white star); X10

The greatest number of liver alterations $(71.42 \%)$ were observed at Tk site, during both seasons. Fish sampled from Bs site and Ks site displayed the lowest number of liver alterations (2 alterations, i.e. $28.57 \%$ ) respectively during rainy and dry seasons. Regressive changes were found to be more prevalent from all samples sites, compared to any other of the reaction patterns. Liver necrosis was prevalent in more than $40 \%$ of samples regardless of the site and seasons.

\section{Semi-quantitative analysis}

The results of semi-quantitative assessment of the liver alterations in African catfish from Bagoue River were showed in Table 3. The Kruskall-Wallis test applied revealed a significant difference $(p<0.05)$ between sites during the dry season. The liver index ( $\left.\mathrm{I}_{1}\right)$ (30 at Tk site and 21 at Ks site) was higher downstream than upstream (10 at Bs site and 15 at Bg site). These index did not vary (Mann-Whitney, $p>0.05$ ) between seasons as well as between male and female. 


\section{Macrothink}

Table 3. Liver index $\left(\mathrm{I}_{1}\right)$ in Clarias gariepinus at sampling sites and seasons

\begin{tabular}{|c|c|c|c|}
\hline \multirow{2}{*}{ Climatic seasons } & \multirow{2}{*}{ Sites } & \multicolumn{2}{|c|}{ Liver index $\left(\mathrm{I}_{1}\right)$} \\
\hline & & Male & Female \\
\hline \multirow{5}{*}{ Wet season } & $\mathrm{Tk}$ & $11.5 \pm 3.53$ & $13 \pm 1.41$ \\
\hline & $\mathrm{Ks}$ & $15 \pm 4.24$ & $14.5 \pm 6.36$ \\
\hline & $\mathrm{Bs}$ & $10 \pm 1.41$ & $10.5 \pm 6.31$ \\
\hline & $\mathrm{Bg}$ & $19.5 \pm 2.12$ & $12 \pm 5.65$ \\
\hline & Average & $14 \pm 4.22$ & $12.5 \pm 5.17$ \\
\hline \multirow{5}{*}{ Dry season } & $\mathrm{Tk}$ & $30 \pm 1.41^{\mathrm{a}}$ & $23 \pm 5.65$ \\
\hline & $\mathrm{Ks}$ & $21 \pm 5.65^{\mathrm{a}}$ & $27.5 \pm 0.7$ \\
\hline & Bs & $10 \pm 4.24^{b}$ & $19 \pm 4.24$ \\
\hline & $\mathrm{Bg}$ & $15 \pm 2.82^{b}$ & $15.5 \pm 9.19$ \\
\hline & Average & $19 \pm 8.60$ & $21.25 \pm 5.17$ \\
\hline
\end{tabular}

$a$ and $b$ indicate a significant difference between sites $(\mathrm{p}<0.05)$ during dry season.

\subsection{Overall Health Status of Fish}

The total index was calculated by sex and season for all sampling sites (Table 4) in order to determine and compare the general health status of fish.

Table 4. Total Index (IT) in Clarias gariepinus for each sampling site and climatic seasons

\begin{tabular}{lcll}
\hline \multirow{2}{*}{ Climatic seasons } & \multirow{2}{*}{ Sites } & \multicolumn{2}{c}{ Total index (IT) } \\
\cline { 3 - 4 } & & \multicolumn{1}{c}{ Male } & \multicolumn{1}{c}{ Female } \\
\hline \multirow{4}{*}{ Wet season } & Kk & $27.5 \pm 3.18$ & $45.5 \pm 13.78$ \\
& Bs & $24.5 \pm 3.18$ & $26.5 \pm 3.88$ \\
& Bg & $25 \pm 9.89$ & $21.5 \pm 1.76$ \\
& Average & $\mathbf{2 7} \pm \mathbf{2 . 9 7}$ & $\mathbf{3 0 . 1 2} \pm \mathbf{1 0 . 5 4}$ \\
\hline \multirow{3}{*}{ Dry season } & Tk & $46.5 \pm 9.54$ & $38.5 \pm 5.30$ \\
& Ks & $41 \pm 0.7$ & $38.5 \pm 11.68$ \\
& Bs & $33.5 \pm 9.54$ & $40.5 \pm 1.76$ \\
& Bg & $28.5 \pm 0.06$ & $27 \pm 2.82$ \\
& Average & $\mathbf{3 7 . 3 7} \pm \mathbf{7 . 9 6}$ & $\mathbf{3 6 . 1 2} \pm \mathbf{6 . 1 5}$ \\
\hline
\end{tabular}

No significant differences (Kruskall-Wallis, $p>0.05$ ) were reported in Clarias gariepinus health between the prospected sites regardless of climatic seasons. Seasonally, a similarity in total index was also observed between the rainy and dry seasons (Mann-Whitney, $p>0.05$ ). Also, the comparison of total index between the sexes did not reveal any variation between male and female of this species regardless of the climatic season (Mann-Whitney, $p>0.05$ ). 
Overall, the total index was ranked between level $3\left(26 \leq \mathrm{I}_{\mathrm{T}} \leq 35\right)$ and level $4\left(\mathrm{I}_{\mathrm{T}}>35\right)$ in both sexes and both seasons at the sites. These levels suggest that organ tissues have undergone severe to very severe alterations.

\subsection{Factor Condition}

Means of Clarias gariepinus condition index values are given in Table 5. Average condition coefficient $(\mathrm{K})$ data are greater than 1 for each site and season. No significant differences in the condition index (Kruskall-Wallis, $p>\mathbf{0 . 0 5}$ ) were observed between fish sampled at different sites. Similarly, the Mann-Whitney test did not reveal any significant seasonal variation in the condition index.

Table 5. Length, weight and condition factor (K) of Clarias gariepinus caught in Bagoue River from August 2018 to April 2019

\begin{tabular}{lcccccc}
\hline Sites & \multicolumn{3}{c}{ Wet season } & \multicolumn{3}{c}{ Dry season } \\
\cline { 2 - 7 } & Length $(\mathrm{cm})$ & Weight $(\mathrm{g})$ & $\mathrm{K}$ & Length $(\mathrm{cm})$ & Weight $(\mathrm{g})$ & $\mathrm{K}$ \\
\hline $\mathrm{Tk}$ & $29.26 \pm 4.91$ & $279.5 \pm 96.41$ & $1.10 \pm 0.21$ & $32.2 \pm 8.25$ & $421 \pm 346.51$ & $1.12 \pm 0.14$ \\
$\mathrm{Ks}$ & $32.26 \pm 7.50$ & $444.5 \pm 265.38$ & $1.15 \pm 0.06$ & $22.35 \pm 4.33$ & $142.5 \pm 97.83$ & $1.14 \pm 0.13$ \\
$\mathrm{Bs}$ & $30.53 \pm 9.77$ & $398.87 \pm 448.24$ & $1.09 \pm 0.10$ & $29.82 \pm 7.12$ & $342.25 \pm 221.94$ & $1.16 \pm 0.12$ \\
$\mathrm{Bg}$ & $29.21 \pm 8.56$ & $359.33 \pm 379.91$ & $1.14 \pm 0.05$ & $25.33 \pm 7.90$ & $247.07 \pm 252.77$ & $1.16 \pm 0.16$ \\
\hline
\end{tabular}

\section{Discussion}

The present study is the first to focus on the target fish reproduction disturbances and also on different types of gonad and liver alterations. Mercury was targeted because of its intensive and majority use in the exploitation of artisanal gold mines in the Bagoue watershed, especially in the Tengrela region at downstream (Kone, 2017).

In the studied organs, level of T-Hg was significantly elevated in the ovary and testis from upstream sites. Several factors such as organ-specific biological activity and metabolism actively contribute to changes in the rates of incorporation of toxic metals into the body's various tissues (Gorski et al., 2003). Also, interactions between the physical and chemical characteristics of environment influence the retention of chemical pollutants by biological organisms (Kainz et al., 2003; Mille et al., 2018). There was also a seasonal difference in $\mathrm{T}-\mathrm{Hg}$ content in ovary. The high level of the metal in this organ during the dry season could be due to its high accumulation in the aquatic environment, especially in sediment during this period. Moreover, the significant seasonal changes in ovary tissue may be due to differences in water quality, maturity state of gonads, environmental conditions (Heba and Mohamed, 2019). According to Thomassin and Touze (2003) the tendency of metal to bio accumulate in gonads during dry season could be explained by its ability to bind to proteins transferred for gametic metabolism.

For the specie studied, all germ cell stages involved in gametogenesis were observed in males and females. However, in males, structural abnormalities of testicular tissues have been observed. Indeed, the effects of pollutants on the fish testis are widely documented in the literature (Linares et al., 2005; Schwindt et al., 2008; Drevnick et al., 2008; Castro-González 
and Méndez-Armenta, 2008; Agohessi et al., 2015; Oreins, 2016; Sayed and Younes, 2017; Pèlèbè et al., 2017; Van Dyk, 2018; Funmilayo et al., 2019; Heba and Mohamed, 2019). Alteration due to the overall disorganization of seminiferous tubes structure and fibrosis (the highest prevalence rate) could be explained by damage to the interstitial cells surrounding the seminiferous tubes. A relationship between heavy metals and the presence of testis tubules damages has been reported in other studies (Pieterse, 2004; Linares et al., 2005; Funmilayo et al., 2019). Alteration of testicular cells can affect reproductive performance by disrupting the production of sex hormones and producing poor quality sperm (Pieterse, 2004; Linares et al., 2005).

As in testis, several alterations were observed in ovarian tissue. Among the alterations of major factor, atretic follicles, fibrosis and necrosis were widespread in gonadal tissues. According to Mehta et al. (2015), atresia may be due to environmental stress. It is an abnormality of endocrine disruption induced by chemicals of a polluting nature (Leino et al., 2005). But follicular atresia may be associated with other factors, including overcrowding (Levavi-Sivan et al., 2004; Unal et al., 2007), lack of males (Tripel and Harvey, 1990) or nutritional deficiencies (Cerda et al., 1995). Atresia is a process of irreversible degeneration by which the oocyte loses its integrity and is eliminated before ovulation. Therefore, atretic follicle may be one of the causes of the decline in reproductive success. The effect of pollutants on reproductive success is corroborated by some authors (Roex et al., 2001; Daouk et al., 2011). The melanomacrophage centers (MMCs) examined in this study act as focal deposits for resistant intracellular bacteria, of all chronic infections that can develop and are associated with severe inflammatory lesions. In a state of environmental stress, these MMCs are growing size and have been proposed as effective indicators for water quality (Steinel and Bolnick, 2017; Sayed and Younes, 2017). Histological effects similar to those found in the present study have been described by authors in fish exposed to doses of insecticides or heavy metals (Marty et al., 2003; Agbohessi et al., 2015; Oreins, 2016; Ahamad et al., 2019; Funmilayo et al., 2019). Alterations in ovarian follicles and spermatogenic cells may reflect damage to the process of gametogenesis and may affect the number of gametes produced, which may reduce the reproductive capacity of individuals over the long term (Arellano-Aguilar and Mac1'as-Garc1'a 2008).

Liver tissues also underwent qualitative and semi-quantitative histological analysis. The detoxifying function of the liver makes it particularly exposed to contaminants. That justifies its use as a reference for the analysis of damage caused by chemical compounds (Amaral et al., 2002). Various liver lesions were examined with a higher prevalence and a more pronounced state of alteration in the present study. The high level of mercury in liver could explain these results. Indeed, liver histological changes associated with mercury or other pollutants exposure have been sufficiently documented in many studies (Schwindt et al., 2008; Marchand et al., 2009; Vergilio et al., 2012; Van Dyk et al., 2012; Oliva et al., 2013; Maceda-Veiga et al., 2013; Stentiford et al., 2014; Dane et al., 2017; Lukhwareni et al., 2018). Most of the alterations identified in liver are reversible. But the persistence of stressors disrupts the function of nutrient synthesis while a correlation has been established between hepato-somatic and gonado-somatic relationships. This correlation reflects the use of liver 
reserves during the maturation of gonads (Bouhali et al., 2015).

Based on liver and gonad histology, the total index above 35 in African catfish at downstream sites suggests that the organs examined suffered severe damage unlike upstream sites where mild to moderate alterations have been observed. Paradoxically, mercury levels were higher in gonads from upstream sites. This data therefore suggests a combined effect of several chemical parameters in severe tissue damage of gonads from downstream. The analysis of the general health indicates a marked deterioration. The effect of anthropogenic impact appears to be visible downstream as the concentration of chemical pollutants and exposure time determine the severity of the damage (Vergilio et al., 2012). The qualitative or quantitative indicator of fish health used in this study has been widely discussed in the literature and its selection reflects the overall organizational health of fish (Van dyk et al., 2009b; Van dyk et al., 2012; Agohessi et al, 2015). Taking into consideration the histological results, response between both sexes suggests that ovary appeared to be more sensitive than testes to chemical contamination as heavy metals. These results are contrary to those evoked by Ibtissem et al. (2009) in the Bizerta Lagoon, Tunisia.

The results of the condition factor suggest that at the current state of pollution, the effect of mercury and correlatively the over pollutants has not reached the individual level in the fish population. Nevertheless, exposure of fish to mercury can disrupt food search and the rate at which prey is caught (Barst, 2015). Likewise, mercury has the ability to cause oxidative stress in fish (Scheuhammer et al., 2012). In terms of fish reproduction, it is able to affect organs such as the hypothalamus and pituitary gland that produce reproductive hormones (Scheuhammer et al., 2012).

\section{Conclusion}

Fish histology was used as a tool to monitor the health status in an area where the continued use of mercury occurs by implementing qualitative and quantitative assessment methods. The results showed the existence of various alterations in the tissues of organs studied both downstream and upstream area. Furthermore, this work suggests that the exposure to mercury, pollutant with reproductive disruptor ability has a spatial distribution which approves the utility of $C$. gariepinus as a fish sentinel model in Bagoue River. It can also be concluded that, despite the alterations identified in the histological assessment, the organs of Bagoue River fish seem to be in a functional state, and therefore the fish health in this population seems not to be severely compromised. But in order to prevent any health risks, we suggest an analysis of all the chemical pollutants that could alter the fish reproductive organs in the Bagoue River. Ultimately, given the high health risks associated with the consumption of contaminated fish, an analysis of mercury levels in the local population body is necessary.

\section{Abbreviations}

AFNOR: French Agency for Standardization; CCME: Canadian Council of Environment Ministers; CEAEQ: Quebec's Center of Expertise and Environmental Analysis; UNEP: United Nation of Environmental Program; WHO: World Health Organization. 


\section{Acknowledgements}

We are grateful to Mr. Cisse, Technician at Pathological and Anatomy Laboratory of the Medical Sciences Training and Research Unit (Felix Houphouët Boigny University, Abidjan, Côte d'Ivoire) for the histological cuts of the fish organs. This study was supported by the Natural Environments and Biodiversity Conservation Laboratory, Department of Biological Sciences, Felix Houphouët Boigny University, Abidjan, Côte d'Ivoire.

\section{References}

AFNOR. (1997). Water quality, collection of French standards, AFNOR Editions, Paris, 46p.

Agbohessi, P. T., Ibrahim, I. T., Ouédraogo, A., Thierry, J., Mandiki, S. N. M., \& Kestemont, P. (2015). Assessment of the health status of wild fish inhabiting a cotton basin heavily impacted by pesticides in Benin (West Africa). Science of the Total Environment, 506, 567-584. https://doi.org/10.1016/j.scitotenv.2014.11.047

Ahmad, M. A., Mohamed, A-E., Hassan, M. M., \& Mohamed, M. A. (2019). Effect of heavy metals on the ovary of Tilapia zillii in some canals of Nile Delta area, Egypt. Egyptian Journal of Aquatic Biology and Fisheries, 23(3), 329-345. https://doi.org/10.21608/ejabf.2019.45670

Amaral, A. F., Alvarado, N., Maria, G. I., Cunha, R., Hylland, K., \& Soto, M. (2002). Autometallography and metallothione in immunohistochemistry in hepatocytes of turbot (Scophthalmus maximus L.) after exposure to cadmium and depuration treatment. Biomarkers, 7, 491-500. https://doi.org/10.1080/1354750021000034843

Arellano-Aguilar, O., \& Mac1'as-Garc1'a, C. (2008). Exposure to pesticides impairs the expression of fish ornaments reducing the availability of attractive males. Proc Biol Sci, 275, 1343-1350. https://doi.org/10.1098/rspb.2008.0163

Barst, D. B. (2015). Spéciation hépatique et distribution tissulaire et sub-cellulaire du mercure: Effet sur la toxicité chez les poissons, Thèse de Doctorat, Institut National de la recherche scientifique, Université de Québec, Canada, 194p.

Bernet, D., Schmidt, H., Meier, W., Berkhardt-Holm, P., \& Wahli, T. (1999). Histopathology in fish: proposal for a protocol to assess aquatic pollution. Journal of Fish Diseases, 22(1) 25-34. https://doi.org/10.1046/j.1365-2761.1999.00134.x

Berté, S., N'Doua, R. E., Kamelan, M. T., \& Kouamelan, E. P. (2019). First Data on Zooplankton Community Structure and Abundance of Kankelaba River in Côte d'Ivoire (Bagoe Tributary, Basin Niger). Nature and Sciences, 17(8), 125-135. Retrived from DOI: 10.7537/marsnsj170819.18

Bouhali, Z. F., Lechekhab, S., Ladaimia, S., Bedairia, A., Amara, R., \& Djebar, A. B. (2015). Reproduction et maturation des gonades de Sardina pilchardus dans le golfe d'Annaba (Nord-Est algérien). Cybium, 39(2), 143-153.

Castro-González, M. I., \& Méndez-Armenta, M. (2008). Heavy metals: implications associated 
to fish consumption. Environmental Toxicology and Pharmacology, 26, 263-271. https://doi.org/10.1016/j.etap.2008.06.001

CCME. (2011). Manual of sampling protocols for water quality analysis in Canada. In CCME, Water-publication, 219p.

CEAEQ. (2015). Détermination des solides en suspension totaux et volatils : méthode gravimétrique, Ministère du Développement durable, de l'Environnement et de la Lutte contre les changements climatiques du Quebec, Canada, 11p.

Cerda, J., Zanuy, S., Camillo, M., Ramos, J., \& Serrano, R. (1995). Short and long term dietary effects on female sea bass (Dicentrarchus labrax), seasonal changes in plasma profiles of lipids and sex steroids in relation to reproduction. Comp. Bioch. Phys., 111(1), 83-94. https://doi.org/10.1016/0742-8413(95)00018-3

Dane, H., \& Turgay, Ş. (2017). A histopathological study on the freshwater fish species chub (Squalius cephalus) in the Karasu River, Turkey. Turkish Journal of Zoology, 41(1), 1-11. https://doi.org/10.3906/zoo-1509-21

Daouk, T., Larcher, T., Roupsard, F., Lyphout, L., Rigaud, C., Ledevin, M.,... Cousin, X. (2011). Long-term food-exposure of zebrafish to PCB mixtures mimicking some environmental situations induces ovary pathology and impairs reproduction ability. Aquatic Toxicology, 105, 270-278. https://doi.org/10.1016/j.aquatox.2011.06.021

Donkor, A. K., \& Adimado, A. A. (2016). Influence of mining related activities on levels of mercury in water, sediment and fish from the Ankobra and Tano River basins in South Western Ghana. Environmental Systems Research, 5, 5-10. https://doi.org/10.1186/s40068-016-0055-4

Drevnick, P., Roberts, A., Otter, R., Hammerschmidt, C., Klaper, R., \& Oris, J. (2008). Mercury toxicity in livers of northern pike (Esox lucius) from Isle Royale, USA. Comparative Biochemistry and Physiology Part C: Toxicology \& Pharmacology, 147(3), 331-338. https://doi.org/10.1016/j.cbpc.2007.12.003

Funmilayo, V. D., Abdullahi, A., Idowu, A. A., \& Adebayo, A. O. (2019). Histopathological Biomarkers of exposure to Monocyclic Aromatic Hydrocarbons in Clarias gariepinus. Sciences and Technology, 11(1), 34-44. https://doi.org/10.30880/jst.2019.11.01.004

Ghestem, J. P., Crouzet, C., \& Girardot, N. (2008). Geochemical bottons estimation in trace elements of continental surface water and groundwater: Charge book for analysis and collection. Final report, 47p.

Gorski, P. R., Cleckner, L. B., Hurley, J. P., Sierszen, M. E., \& Armstrong, D. E. (2003). Factors affecting enhanced mercury bioaccumulation in inland lakes of Isle Royale National Park, USA. Sciences of Total Environment, 304, 327-348. https://doi.org/10.1016/S0048-9697(02)00579-X

Heba, H. A-K., \& Mohamed, H. M. (2019). Bioaccumulation of Heavy Metals and Physiological/Histological Changes in Gonads of Catfish (Clarias gariepinus) inhabiting Lake Maryout, Alexandria, Egypt. Egyptian Journal of Aquatic Biology \& Fisherie, 23(2), 363-377. https://doi.org/10.21608/ejabf.2019.32036 
Ibtissem, L., Mossadok, B-A., \& Oum, B-H. (2009). Gonadosomatic index and gonad histopathology of Gobius niger (Gobiidea, Teleost) from Bizerta lagoon (Tunisia): Evidence of reproduction disturbance. Fisheries Research, 100(3), 266-273. https://doi.org/10.1016/j.fishres.2009.08.009

Kainz, M., Lucotte, M., \& Parrish, C. C. (2003). Relationships between organic matter composition and methyl mercury content of offshore and carbon-rich littoral sediments in an oligotrophic lake. Canada Journal of Fisheries and Aquatic Sciences, 6, 888-896. https://doi.org/10.1139/f03-075

Kone, B. (2017). Gold fever and the future of rural activities in the department of Tengrela (North Côte d'Ivoire). Geography Tropical Institute, Félix Houphouët-Boigny University, Abidjan cocody, Côte d'Ivoire. Revue Ivoirienne de Géographie des Savanes, 2, 2521-2535.

Leino, R. L., Jensen, K. M., \& Ankley, G. T. (2005). Gonadal histology and characteristic histopathology associated with endocrine disruption in the adult fathead minnow (Pimephales promelas). Environ Toxicol Pharmacol, 19, 85-98. https://doi.org/10.1016/j.etap.2005.05.010

Levani-Sivana, B., Vaimana, R., Sachsb, O., \& Tzchorib, I. (2004). Spawing introduction and hormonal levels during final oocyte maturation in the silver perch. Bidyanus bidyanus. Aquaculture, 229, 419-431. https://doi.org/10.1016/S0044-8486(03)00349-1

Linares, V., Albina, M. L., \& Belleis, M. (2005). Combined action of uranium and stress in the rat: II. Effects on male reproduction. Toxicology Letters, 158(3), 176-185. https://doi.org/10.1016/j.toxlet.2005.03.011

Lukhwareni, R., \& Van Dyk, C. (2018). Histology and ultrastructure of hepatic nodular alterations in Clarias gariepinus (Burchell, 1822). Journal of Fisheries Diseases, 41(12), 1859-1870. https://doi.org/10.1111/jfd.12900

Maceda-Veiga, A., Monroy, M., Navarro, E., Viscor, G., \& De Sostoa, A. (2013). Metal concentrations and pathological responses of wild native fish exposed to sewage discharge in a Mediterranean river. Science of the Total Environment, 449, 9-19. https://doi.org/10.1016/j.scitotenv.2013.01.012

Marchand, M. J., Van Dyk, J. C., Pieterse, G. M., Barnhoorn, I. E. J., \& Bornman, M. S. (2009). Histopathological alterations in the liver of the sharptooth catfish Clarias gariepinus from polluted aquatic systems in South Africa. Environmental Toxicology, 24(2), 133-147. https://doi.org/10.1002/tox.20397

Marty, G. D., Hoffmann, A., Okihiro, M. S., Hepler, K., \& Hanes, D. (2003). Retrospective analyses: bile hydrocarbons and histopathology of demersal rockfish in Prince William sound, Alaska, after the Exxon Valdez oil spill. Marine Environmental Research, 56(5) , 569-584. https://doi.org/10.1016/S0141-1136(03)00043-6

Mason, R. P., Zofia, B., Gunnar, H., Koffi, M. Y., Mariame, C., \& Safiatou, C., (2019). An assessment of the impact of artisanal and commercial gold mining on mercury and methylmercury levels in the environment and fish in Cote d'Ivoire. Science of Total 
Environment, 665, 1158-1167. https://doi.org/10.1016/j.scitotenv.2019.01.393

McHugh, J. K., Smit, N. J., Van Vuren, J. H. J., \& Van Dyk, J. C. (2013). Health of sharptooth catfish Clarias gariepinus in Pongolapoort Dam, South Africa: a comprehensive study. African Journal of Aquatic Science, 38(2), 211-219. https://doi.org/10.2989/16085914.2012.757214

Mehta, M., Mukesh, A., \& Ambani, M. (2015). Effects of reproductive biology on heavy metal pollution on the histopathological structure of gonads in India Adv. Aquaculture. Fish Manage, 3(2), 223-227.

Mille, T., Mauffret, A., Baudrier, J., Wessel, N., \& Bouchoucha, M. (2018). Etude de la contamination chimique chez quatre espèces de poisson en Méditerranée. Rapport final des actions 2017-2018 du dispositif de suivi CONTAMED, 62p. Retrived from https://archimer.ifremer.fr/doc/00458/56962

N’da, S. A., Etilé, R. N., N'zi, K. G., Berté, S., \& N’douba, V. (2015). Composition and Distribution of Zooplankton Relationship to Environmental Factor in a Tropical River: (Bagoe, Côte d'Ivoire). International Research Journal of Biological Sciences, 4(11), 1-11, ISSN 2278-3202.

Niane, B., Moritz, R., Guédron, S., Ngom, P. M., Pfeifer, H. R., Mall, I., \& Pote, J. (2014). Effect of recent artisanal small-scale gold mining on the contamination of surface river sediment: Case of Gambia River, Kedougou, Journal Geochemical Exploration, 144, 517-527. https://doi.org/10.1016/j.gexplo.2014.03.028

Oliva, M., Vicente-Martorell, J. J., Galindo-Riaño, M. D., \& Perales, J. A. (2013). Histopathological alterations in Senegal sole, Solea senegalensis, from a polluted Huelva estuary (SW, Spain). Perales Fish Physiol Biochem, 39(3), 523-545. https://doi.org/10.1007/s10695-012-9717-y

Oreins, N. (2016). Perturbations endocrines induites par l'Acer 35EC, un insecticide à base d'acétamipride et de lambda-cyhalothrine, chez le poisson Oreochromis niloticus exposés à des doses chroniques. Mémoire de Master en Biologie des organismes et écologie, Université Catholique de Louvain, 70p.

Osman, A. G. M., \& Werner, K. (2010). Water quality and heavy metal monitoring in water, sediments and tissues of the African Catfish, Clarias gariepinus from the River Nile, Egypt. Journal of environmental protection, 1(04), 389-400. https://doi.org/10.4236/jep.2010.14045

Pèlèbè, E. O. R., Toko, I. A., Imorou, T. I., Guedegba, N. L., Agbohessi, T. P., Zoclanclounon, $\mathrm{H}$ et al. (2017). Histologie des gonades mâle et femelle du tilapia oreochromis niloticus exposé aux pesticides agricoles dans les retenues d'eau du Nord-Bénin. Annales de l'université de Parakou, série Sciences naturelles-Agronomie, 7(1), 41-46.

Pieterse, G. M. (2004). Histopathological changes in the testis of Oreochromis mossambicus (Cichlidae) as a biomarker of heavy metal pollution. PhD Thesis, The Rand Afrikaans University, Johannesburg, South Africa, 183p.

Roex, E. W. M., Giovannangelo, M., \& van Gestel, C. A. M. (2001). Reproductive Impairment 
in the Zebrafish, Danio rerio, upon Chronic Exposure to 1,2,3-Trichlorobenzene. Ecotoxicology and Environmental Safety, 48, 196-201. https://doi.org/10.1006/eesa.2000.2029

Sayed, A. H., \& Younes, H. A. (2017). Melanomacrophage centers in Clarias gariepinus as an immunological biomarker for toxicity of silver nanoparticles. Journal of microscopy and ultrastructure, 5(2), 97-104. https://doi.org/10.1016/j.jmau.2016.07.003

Scheuhammer, A. M., Basu, N., Evers, D. C., Heinz, G. H., Sandheinrich, M. B., \& Bank, M. S. (2012). Ecotoxicology of mercury in fish and wildlife In: Bank M.S. Edition: mercury in the Environment pattern and process, University of California, USA, pp223-238. https://doi.org/10.1525/california/9780520271630.003.0011

Schwindt, A. R., Fournie, J. W., Landers, D. H., Schreck, C. B., \& Kent, M. L. (2008). Mercury concentrations in salmonids from western US national parks and relationships with age and macrophage aggregates. Environmental Science of Technology, 42(4), 1365-1370. https://doi.org/10.1021/es8002603

Short, S., \& Meyers, T. R. (2001). Histology in Finfish. National Wild Fish Health Survey Laboratory Procedures Manual. Version 1.0. Alaska Fish and Game C.F. Division.

Steinel, N. C., \& Bolnick, D. I. (2017). Melanomacrophage centers as a histological indicator of immune function in fish and other poikilotherms. Frontiers in immunology, 8, 827. https://doi.org/10.3389/fimmu.2017.00827

Stentiford, G. D., Massoud, M. S., Al-Mudhhi, S., Al-Sarawi, M. A., Al- Enezi, M., \& Lyons B. P. (2014). Histopathological survey of potential biomarkers for the assessment of contaminant related biological effects in species of fish and shellfish collected from Kuwait Bay, Arabian Gulf. Marine Environmental Research, 60-67. https://doi.org/10.1016/j.marenvres.2014.03.005

Thomassin, J. F., \& Touze, S. (2003). Le mercure et ses composés : comportement dans les sols, les eaux et les boues de sédiments. Rapport Final, BRGM/RP-51890-FR, 121p.

Tripel, E-A., \& Harvey, H. H. (1990). Ovarian atresia and sex ratio imbalance in white sucker. C. Commersoni. J. Fish. Biol., https://doi.org/10.1111/j.1095-8649.1990.tb05598.x

Unal, G., Turkoglu, V., Oguz, A. R., \& Kaptaner, B. (2007). Gonadal histology and some biochemical characteristics of Chalcalburnus tarichi (Pallas, 1811) having abnormal gonads. Fish Physiol. Biochem., 33, 153-165. https://doi.org/10.1007/s10695-006-9126-1

UNEP. (2002). Evaluation Mondiale du Mercure. Programme de Nation Unies pour l'Environnement, substances chimiques, Genève, Suisse, 306p.

Van Dyk, J. C. (2018). Histology and ultrastructure of hepatic nodular alterations in Clarias gariepinus. Journal of fish diseases, 41(12), 1-12. https://doi.org/10.1111/jfd.12900

Van Dyk, J. C., Cochrane, M. J., \& Wagenaar, G. M. (2012). Liver histopathology of the sharptooth catfish Clarias gariepinus as a biomarker of aquatic pollution. Chemosphere, 87(4), 
301-311. https://doi.org/10.1016/j.chemosphere.2011.12.002

Van Dyk, J. C., Marchand, M. J., Pieterse, G. M., Barnhoom, I. E. J., \& Bornman, M. S. (2009a). Histological changes in the gills of Clarias gariepinus from a polluted South African. African Journal of Aquatic Sciences, 34(3), 1608-1727. https://doi.org/10.2989/AJAS.2009.34.3.10.986

Van Dyk, J. C., Marchand, M. J., Smit, N. J., \& Pieterse, G. M. (2009b). A histology-based fish health assessment of four commercially and ecologically important species from the Okavango Delta panhandle, Botswana. African Journal of Aquatic Science, 34(3), 273-282. https://doi.org/10.2989/AJAS.2009.34.3.9.985

Van Dyk, J. C., Pieterse, G. M., \& Van Vuren, J. H. J. (2007). Histological changes in the liver of Oreochromis mossambicus (Cichlidae) after exposure to cadmium and zinc. Ecotoxicology and Environmental Safety, 66(3), 432-440. https://doi.org/10.1016/j.ecoenv.2005.10.012

Vergilio, C. S., Carvalho, C. E. V., \& Melo, E. J. T. (2012). Accumulation and histopathological effects of mercury chloride after acute exposure in tropical fish Gymnotus carapo. Journal of Chemical Health Risks, 2(4), 01-08. ISSN: 2251-6719.

WHO. (2007). Preventing disease through healthy environments; Exposure to mercury: a major public health concern, Document Production Services, Geneva, Switzerland, 167p.

Zuzia, D., Alan, M., \& Helbig de Bulzaz, H. (2017). L'eldorado ouest-africain: Cartographie du commerce illicite de l'or en Côte d'Ivoire, au Mali et au Burkina Faso, Partenariat Afrique Canada, ISBN : 978-1-897320-38-9, 28p.

\section{Copyrights}

Copyright for this article is retained by the author(s), with first publication rights granted to the journal.

This is an open-access article distributed under the terms and conditions of the Creative Commons Attribution license (http://creativecommons.org/licenses/by/4.0/) 